\title{
Marine intrusions in a coastal lagoon enhance the negative effect of solar UV radiation on phytoplankton photosynthetic rates
}

\author{
Daniel Conde ${ }^{1}$, Luis Aubriot ${ }^{1}$, Sylvia Bonilla ${ }^{1}$, Ruben Sommaruga ${ }^{2, *}$ \\ ${ }^{1}$ Limnology Section, Faculty of Sciences, University of Uruguay (UDELAR), Iguá 4225, 11400 Montevideo, Uruguay \\ ${ }^{2}$ Institute of Zoology and Limnology, University of Innsbruck, Technikerstr. 25, 6020 Innsbruck, Austria
}

\begin{abstract}
Between March 1997 and May 1999, we studied the effect of solar UV-B (290 to $320 \mathrm{~nm}$ ) and UV-A (320 to $400 \mathrm{~nm}$ ) radiation on phytoplankton photosynthetic rates in a shallow coastal lagoon with periodic exchange with the Atlantic Ocean. In particular, we assessed whether the exchange with the ocean affected the severity of photosynthetic inhibition. During events of marine intrusion, the UV attenuation coefficient $\left(K_{\mathrm{d}}\right)$ in the brackish zone decreased up to $70 \%$ of the values observed under the influence of the freshwater discharge. The highest inhibition of the PARsaturated photosynthetic rates by UV radiation (up to $55 \%$ ) was observed in summer at the brackish zone in association with marine intrusion events. In the freshwater zone, the highest inhibition was up to 3-fold lower than in the brackish area due to higher $K_{\mathrm{d}}$ values in the UV range. On average for the entire system, near-surface primary production was reduced by ca. $25 \%$, and the contribution by UV-A and UV-B was close to 2:1. Our results provide a baseline for future comparisons at a latitude where predicted trends in reduction of stratospheric ozone are significant. However, hydrological changes affecting river discharge and communication frequency with the ocean appear to be more important for the UV underwater climate and primary production than the expected increase in incident UV-B fluxes.
\end{abstract}

KEY WORDS: UV-A · UV-B · CDOM · Microalgae sensitivity · Primary production · Hydrological regime $\cdot$ ENSO

\section{INTRODUCTION}

Assessing the impact of solar ultraviolet radiation (UVR, 290 to $400 \mathrm{~nm}$ ) on aquatic ecosystems requires information about biological responses at several trophic levels. For this purpose, the identification of vulnerable environments is crucial. While most of the research on UV effects in aquatic systems has concentrated on oceans and lakes, little information on the susceptibility of shallow estuaries and coastal lagoons is available, despite that they rank among the most productive aquatic ecosystems (Comín \& Valiela 1993, Costanza et al. 1993). In these shallow water bodies,

${ }^{*}$ Corresponding author.

E-mail: ruben.sommaruga@uibk.ac.at the confinement of microalgae and other organisms near the surface may impose a major UV stress (Piazena \& Häder 1994), while it may also facilitate acclimation (Vincent \& Roy 1993).

The effects of solar UVR on natural phytoplankton assemblages from shallow estuaries and coastal lagoons are largely unexplored (Piazena \& Häder 1994, Kuhn et al. 1999). Recently, Banaszak \& Neale (2001) reported that natural phytoplankton assemblages from a shallow estuary of the Chesapeake Bay were highly sensitive to solar UVR throughout the year, especially to UV-B radiation. These authors attributed the high sensitivity of the phytoplankton assemblage to the short-term variability of the optical and chemical conditions in this system. Litchman et al. (2002) presented evidence that nitrogen limitation may 
significantly increase the sensitivity of photosynthesis to inhibition by UVR in estuarine microalgae through less efficient repair, decrease in cell size and in the concentration of photoprotective mycosporine-like amino acids (MAAs).

Estuaries are characterized by the intense exchange of waters of different concentrations of chromophoric dissolved organic matter (CDOM) absorbing in the UVR (Stedmon et al. 2000). The relative dominance of the input of freshwater and marine waters with high and low CDOM concentration, respectively, is the main process governing the underwater UV attenuation in estuarine systems (Kuhn et al. 1999, Conde et al. 2000). This process is largely driven by climatological forces and therefore exhibits large spatial and temporal variability. Given the complex relationships between the UV underwater climate, the vertical mixing process and the phytoplankton response, the hydrodynamical conditions of well-mixed environments must be studied in detail to properly understand the kinetics of photoinhibition and recovery (Köhler et al. 2001, Neale et al. 2001). In particular, biological weighting functions (BWFs) are a valuable tool to describe the effectiveness of UVR on phytoplankton photosynthetic rates and to model the impact of UVR on natural communities receiving fluctuating UV levels such as those living in estuaries (Neale 2001).

The lagoons of the southeastern coast of Uruguay and Brazil may be specially susceptible to UVR due to their shallowness (range of maximum water depth is 0.5 to $5 \mathrm{~m}$, but most commonly $<2 \mathrm{~m}$ depth) and location at latitudes where a significant reduction of stratospheric ozone is predicted for the next decades (Sze et al. 1989). Low ozone concentrations during short periods of time or 'miniholes' have already been detected in South America up to $30^{\circ}$, due to the transport of low ozone air masses following the Antarctic vortex break-up (Kirchhoff et al. 1996). Another relevant feature of these coastal systems is the tight coupling between the rainfall pattern and ENSO events, with flood/drought cycles closely associated to El Niño/La Niña periods (Mechoso \& Pérez-Iribarren 1992, Genta et al. 1998). While dry years prevent the connection of the lagoons with the ocean, high freshwater pulses allow the periodic entry of coastal water masses (i.e. marine intrusions), which occurs with few days to several weeks delay after the discharge of the lagoon into the coastal zone. The extent of the marine intrusions depends basically on the dominance of southeastern strong winds.

In this study, we assessed the effects of solar UV-B ( 290 to $320 \mathrm{~nm}$ ) and UV-A ( 320 to $400 \mathrm{~nm}$ ) radiation on the photosynthetic rate of phytoplankton from a coastal lagoon of the Southern Atlantic Ocean (Laguna de Rocha) with special focus on the potential influence exerted by the hydrological regime on photosynthetic inhibition. The main feature of this system is the periodic occurrence of salinity and turbidity gradients that develop after the mixing of marine and freshwaters. These gradients clearly define 2 areas: one in the north influenced by the freshwater discharge with high turbidity and high nutrient loading, and another in the south, with higher transparency to UVR and lower nutrient concentration (Conde et al. 2000).

\section{MATERIALS AND METHODS}

Study site. Laguna de Rocha is a shallow and large brackish lagoon (mean depth $=0.6 \mathrm{~m}$, area $=72 \mathrm{~km}^{2}$ ) located on the southeastern coast of South America $\left(34^{\circ} 33^{\prime} \mathrm{S}, 54^{\circ} 22^{\prime} \mathrm{W}\right)$. The lagoon is part of a MaB/ UNESCO Biosphere Reserve, and a nursery and feeding area for crustaceans and fish of commercial value as well as for migrating birds (Sommaruga \& Pintos 1991). The system communicates with the sea through a single-mouth inlet on a sand barrier that opens naturally (occasionally by human action) when the water depth is higher than $\sim 1.3 \mathrm{~m}$ (choked-type lagoon). However, the communication with the ocean, which may take place several times per year, does not occur until high wave action at the seaside takes place (e.g. during storms). Other relevant information for Laguna de Rocha can be found elsewhere (Sommaruga \& Pintos 1991, Conde \& Sommaruga 1999).

Sampling and in situ measurements. Two sampling sites were located in the lagoon corresponding to the typical freshwater- and marine-influenced areas (Stns N and S, respectively, each area covering ca. $20 \mathrm{~km}^{2}$ ). Selection of the 2 stations was based on a previous survey of the abiotic, biological (Conde et al. 1999) and bio-optical (Conde et al. 2000) characteristics of the system.

Twenty samplings were performed from March 1997 to June 1999 (excluding winter 1998). During this period, 27 experiments were conducted to test the sensitivity of phytoplankton to solar UVR. Although the lagoon connected with the ocean 9 times during the study, only 4 major marine intrusion events (based on conductivity values) were covered during the study (March 1997, March 1998, August to October 1998, and February 1999). Sixteen experiments corresponded to samples collected from Stn S (marine influenced area) and 11 experiments corresponded to Stn $\mathrm{N}$ (zone dominated by the freshwater discharge). These sites correspond respectively to the Stns B and G on the map shown in Fig. 1 of Conde et al. (2000). Aerial views of the southern and northern zones of the lagoon can be seen at http://zoology.uibk.ac.at/limno/images/ rocha.html. 
Sampling was performed at around 09:00 h local time to avoid sediment resuspension by wind, which commonly occurs after midday. Particular care was taken to avoid artificial resuspension during the sampling. Water samples were collected at ca. $10 \mathrm{~cm}$ depth with a 31 Schindler sampler and kept in dim light either at ca. $15^{\circ} \mathrm{C}$ for the UV experiments or at $4^{\circ} \mathrm{C}$ for all other analyses. Analyses and experiments were carried out at a field station close to the lagoon. For each sampling occasion, the water column was characterized by measuring the water depth, temperature, dissolved oxygen (Horiba OM-14), $\mathrm{pH}$ and conductivity (Horiba D-24).

Irradiances in the UV-A and UV-B wavebands $\left(E_{\mathrm{UV}-\mathrm{A}}\right.$ and $\left.E_{\mathrm{UV}-\mathrm{B}}\right)$ were measured in situ under clear sky conditions with an International Light radiometer (IL1400A) consisting of the broadband SUL033/W (UV-A) and SUL240/W (UV-B) sensors. The effective bandwidth in sunlight of the UV-B sensor is not clearly specified by the manufacturer, but it is assumed to be less than $20 \mathrm{~nm}$ (Kirk et al. 1994) with a peak response at $311 \mathrm{~nm}$ in air. The UV-A sensor measures from 315 to $390 \mathrm{~nm}$ with a peak response at $365 \mathrm{~nm}$. Simultaneously with the UV profiles, photosynthetically available radiation (PAR, 400 to $700 \mathrm{~nm}$ ) profiles were performed with a LI-192SA $2 \pi$ quantum sensor and recorded in a LI-250 (Li-Cor) data logger. Sensors were submersed away from the boat with a rod that allowed depth measurements $( \pm 1 \mathrm{~cm})$. Irradiances at each depth were averaged for 20 to $30 \mathrm{~s}$. Approximately 25 points were measured for each profile. Attenuation coefficients $\left(K_{\mathrm{d}}\right)$ were estimated according to Kirk (1994). The determination coefficient of the $K_{\mathrm{d}}$ estimates was always $>0.96$ and the standard errors $<0.03$. Incident PAR and UV irradiances were registered during the course of the experiments at the incubation site with the same sensors. Irradiances at the incubation depth were calculated using incident values and attenuation coefficients. The stratospheric ozone concentration for this area was obtained from the Earth Probe satellite/TOMS web site at http://jwocky.gsfc.nasa.gov.

Physical, chemical and biological analyses. Suspended inorganic solids (SIS) were estimated gravimetrically (APHA 1995). The organic content of the suspended solids (SOS) were determined as the loss weight after ignition at $450^{\circ} \mathrm{C}$ for $2 \mathrm{~h}$ (APHA 1995). Alkalinity was determined after titration with sulfuric acid, while the concentration of nitrate, soluble reactive phosphorus (SRP) and reactive silicate content were analyzed spectrophotometrically (APHA 1995).

To determine the DOC concentration, $150 \mathrm{ml}$ of water was filtered through Whatman GF/F filters (precombusted at $450^{\circ} \mathrm{C}$ for $2 \mathrm{~h}$ ) using acid-washed glass syringes and stainless steel filter holders. Filtrates were collected in glass bottles (Schott, pre-combusted for at least $2 \mathrm{~h}$ at $475^{\circ} \mathrm{C}$ ), acidified to $\mathrm{pH} 2$ with $\mathrm{HCl}$ and stored at $4^{\circ} \mathrm{C}$ in the dark. A Shimadzu TOC analyzer (Model 5000) with platinized-quartz catalyst for high sensitivity (Benner \& Strom 1993) was used for the analyses. The system was calibrated with standards made with potassium hydrogen phthalate dissolved in Milli-Q water. Concentrations of DOC in Milli-Q water ranged from 0.03 to $0.05 \mathrm{mg} \mathrm{l}^{-1}$.

To determine the concentration of pigments, 0.1 to 0.51 were filtered onto GF/F Whatman filters. Afterwards, filters were sonicated for $1 \mathrm{~min}$ and extracted overnight in the dark at $4{ }^{\circ} \mathrm{C}$ with alkaline $90 \%$ acetone. Extracts were then cleared with GF/C Whatman filters and scanned in a DU-6 Beckman spectrophotometer using $5 \mathrm{~cm}$ cuvettes from 400 to $750 \mathrm{~nm}$ against an acetone reference. The concentration of pigments was estimated according to Jeffrey \& Humphrey (1975). Samples for phytoplankton identification and quantification were preserved with acid Lugol's solution. The identification of microalgal taxa was done by optic microscopy $(1000 \times)$ following Tomas (1997). Abundance was estimated in an inverted microscope with phase contrast, using sedimentation chambers of 5 to $10 \mathrm{ml}$ (Hasle 1978).

UVR treatments and photosynthetic rate estimates. All experiments to estimate the effect of UVR on photosynthetic carbon uptake rates were done from 10:00 to 14:00 h local time under natural solar radiation during clear sky days. Phytoplankton samples taken from each site as previously described were incubated at $10 \mathrm{~cm}$ depth in spherical quartz bottles $6.5 \mathrm{~cm}$ in diameter under 3 treatments: (1) receiving the full solar spectrum (PAR + UV-A + UV-B); (2) wrapped with $64 \mu \mathrm{m}$ thick Mylar-D (Du-Pont de Nemours) to exclude most of the UV-B radiation (i.e. PAR + UV-A); and (3) wrapped with a vinyl chloride foil (CI Kasei) to exclude most of the UVR (i.e. only PAR). The relationship between the chl a-specific photosynthetic rate $\left(P^{\mathrm{B}}\right)$ and the irradiance ( $P-E$ curves) was obtained during short incubations $(4 \mathrm{~h})$ following the simulated in situ method (Lohrenz 1993), in which PAR and UVR gradients are obtained using different layers of neutral density screens covering each bottle. We used 10 to 13 levels of PAR (from 0 to up to $2000 \mu \mathrm{mol} \mathrm{m}{ }^{-2} \mathrm{~s}^{-1}$ ) and UVR, the highest one corresponding to the full PAR (i.e. no neutral density screens). The photosynthetic carbon uptake rate was determined according to the standard ${ }^{14} \mathrm{C}$ procedure of Steeman-Nielsen (1952) with the acidification-bubbling modification (Gätcher et al. 1984). At the end of the incubations, three $5 \mathrm{ml}$ subsamples from each incubation bottle were poured into $20 \mathrm{ml}$ vials for liquid scintillation counting to estimate the photosynthetic rate for each individual incubation. In previous experiments done with samples from the same sites, the variability of the algal ${ }^{14} \mathrm{C}$ 


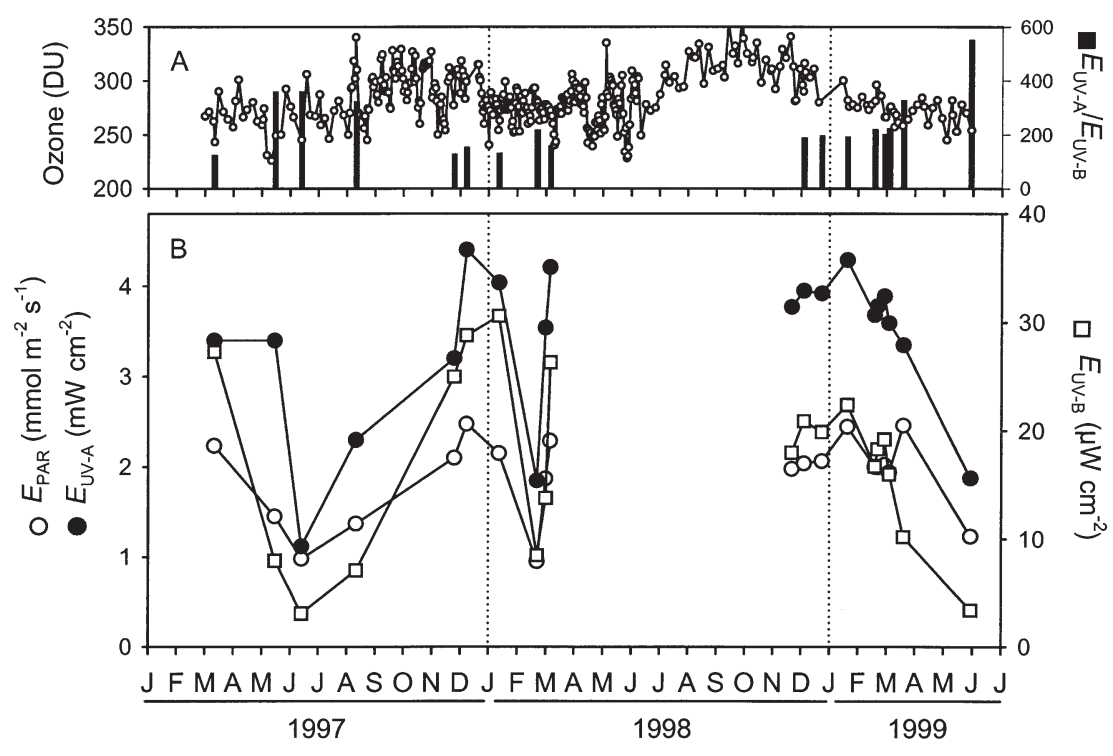

Fig. 1. (A) Weekly average stratospheric ozone concentrations for the latitude of the study area obtained from the TOMS/Earth Probe data and relationship between incident solar UV-A and UV-B irradiances $\left(E_{\mathrm{UV}-\mathrm{A}} / E_{\mathrm{UV}-\mathrm{B}}\right)$ for sampling dates. (B) Incident solar UV-A, UV-B and PAR irradiances $\left(E_{\mathrm{UV}-\mathrm{A}}, E_{\mathrm{UV}-\mathrm{B}}\right.$ and $\left.E_{\mathrm{PAR}}\right)$ at Laguna de Rocha. The values represent the highest irradiance value measured during the days of the experiments. Data for UVR between April and October 1998 are not available

uptake rate was lower among 3 independent replicate samples (coefficient of variation $[\mathrm{CV}]=6.8 \%$ ) than among 3 subsamples from each bottle $(\mathrm{CV}=16.5 \%)$.

Modeling of UV effects. Instead of fitting the observed $P^{\mathrm{B}}$ values to standard $P-E$ curves according to equations commonly used for photosynthesisirradiance modeling, we applied an approach that allowed us to roughly estimate overall phytoplankton sensitivity levels to UVR by calculating broadband weights in the UV-A and UV-B bands. We predicted $P-E$ curves by the following procedure. First, $E_{\mathrm{PAR}}$ (PAR irradiance), $E_{\mathrm{UV}-\mathrm{A}}$, and $E_{\mathrm{UV}-\mathrm{B}}$ for each experiment and treatment were calculated from the irradiances at the incubation depth and the transmittance characteristics of the cut-off materials. According to our transmittance measurements, the $64 \mu \mathrm{m}$ thick Mylar-D foil transmitted $95 \%$ of PAR, $90 \%$ of UV-A and $3 \%$ of UV$\mathrm{B}$, while the vinyl chloride foil transmitted $95 \%$ of $\mathrm{PAR}$, $10 \%$ of UV-A and $0 \%$ of UV-B. Second, actual $E_{\mathrm{PAR}}$, $E_{\mathrm{UV}-\mathrm{A}}$ and $E_{\mathrm{UV}-\mathrm{B}}$ values for each incubation were used to predict $P-E$ curves, according to an irradiancedependent model in which the photosynthetic rate is estimated as a function of PAR, and photoinhibition depends on biologically weighted UV irradiance and PAR (see Banaszak \& Neale 2001):

$$
P^{\mathrm{B}}=P_{\mathrm{S}}^{\mathrm{B}} \tanh \left(E_{\mathrm{PAR}} / E_{\mathrm{S}}\right)\left[1 /\left(1+E^{*}{ }_{\text {inh }}\right)\right]
$$

where $P_{\mathrm{S}}^{\mathrm{B}}$ is the maximum photosynthesis rate in absence of inhibition and $E_{\mathrm{s}}$ is a photosynthesis saturation index calculated as $P^{\mathrm{B}}{ }_{\mathrm{S}} / \alpha^{\mathrm{B}}$, where $\alpha^{\mathrm{B}}$ is the chl $a$ specific photosynthetic efficiency or rate of light uti- lization at subsaturation (Jassby \& Platt 1976). Therefore, $P^{\mathrm{B}}$ is calculated as the result of the potential photosynthesis term $\left(P^{\mathrm{B}} \tanh \left[E_{\mathrm{PAR}} / E_{\mathrm{S}}\right]\right)$ times the inhibition term $\left(1 /\left[1+E^{*}{ }_{\text {inh }}\right]\right)$. The inhibition term is the function of UV irradiance and is expressed as a dimensionless biologically weighted index or $E^{*}{ }_{\text {inh }}$, which substitutes spectral irradiance by our broadband irradiance:

$$
E_{\text {inh }}^{*}=\varepsilon_{\mathrm{PAR}} E_{\mathrm{PAR}}+\varepsilon_{\mathrm{UV}-\mathrm{A}} E_{\mathrm{UV}-\mathrm{A}}+\varepsilon_{\mathrm{UV}-\mathrm{B}} E_{\mathrm{UV}-\mathrm{B}}
$$

where $\varepsilon_{\mathrm{PAR}}, \varepsilon_{\mathrm{UV}-\mathrm{A}}$ and $\varepsilon_{\mathrm{UV}-\mathrm{B}}$ are broadband biological weights or effectiveness for the inhibition of photosynthesis, expressed in units reciprocal to the irradiance. Third, by modifying $\varepsilon_{\mathrm{PAR}}, \varepsilon_{\mathrm{UV}-\mathrm{A}}, \varepsilon_{\mathrm{UV}-\mathrm{B}}$ and $\alpha^{\mathrm{B}}$, predicted $P-E$ curves were fit to the observed $P^{\mathrm{B}}$ data for each incubation with a non-linear estimation using STATISTICA 5.5 (StatSoft). The estimation was performed through a quasi-Newton method and a loss function where (Observed minus Predicted) ${ }^{2}$ was used.

The inhibition of the photosynthesis by UV-A and UV-B was calculated as the relative percentage of the PAR-saturated photosynthetic rate (at $1000 \mu \mathrm{mol} \mathrm{m} \mathrm{m}^{-2}$ $\mathrm{s}^{-1}$ ) predicted for each treatment using Eq. (2) compared to the respective value in the treatment without UVR (Treatment 3). The effect of UV-A was estimated as the difference between Treatments 2 and 3 and the effect of UV-B as the difference between Treatments 1 and 2. To compare samples taken at different times and locations, we calculated the phytoplankton relative productivity, estimated as the $P^{\mathrm{B}}$ for each PAR level standardized by the chl a-specific maximum photosynthesis. 
Statistical analysis. The normality of the data was verified with the Kolmogorov-Smirnov test and the equality of variance assumption was evaluated with the Levene test. Statistical relationships among the variables were tested with the Pearson productmoment correlation (r), corrected according to the Bonferroni method. The significance of the differences between sites were estimated with the paired $t$-test $(t)$. Stepwise multiple linear regressions were performed to evaluate the dependence of the phytoplankton sensitivity on the UV irradiances, water transparency, temperature and nitrate/SRP ratio. To perform these tests, we used SigmaStat 2.03 (SPSS).

\section{RESULTS}

\section{Stratospheric ozone, incident and in situ underwater solar radiation}

The concentration of stratospheric ozone over the study area ranged from 226 DU (Dobson Units) (June 1997) to 367 DU (November 1998) (Fig. 1A). Three out of 27 experiments were carried out under ozone concentrations above $300 \mathrm{DU}, 20$ from 300 to $250 \mathrm{DU}$ and 4 below $250 \mathrm{DU}$.

The incident $E_{\mathrm{PAR}}, E_{\mathrm{UV}-\mathrm{A}}$ and $E_{\mathrm{UV}-\mathrm{B}}$ showed similar trends, with the highest values found in January and the lowest in June (Fig. 1B). The maximum incident irradiance during the study was $2470 \mu \mathrm{mol} \mathrm{m}^{-2} \mathrm{~s}^{-1}$ for
PAR, $4.40 \mathrm{~mW} \mathrm{~cm}{ }^{-2}$ for UV-A and $30.6 \mu \mathrm{W} \mathrm{cm} \mathrm{cm}^{-2}$ for UV-B. The relationship between incident UV-A and UV-B irradiances $\left(E_{\mathrm{UV}-\mathrm{A}} / E_{\mathrm{UV}-\mathrm{B}}\right)$ ranged up to 3 -fold during the study, with the lowest values in summer and the highest during autumn-winter months (Fig. 1A). Except for 3 occasions (21 November 1997, 11 January 1999 and 9 February 1999), the $E_{\mathrm{UV}-\mathrm{A}}$ and $E_{\mathrm{UV}-\mathrm{B}}$ received by the experiments was higher (up to 10-fold for UV-A and up to 100-fold for UV-B) at Stn S (marine influenced) than at Stn $N$ (freshwater influenced) $(p<0.05-t)$. In contrast, PAR intensities were not significantly different among sites $(\mathrm{p}>0.5-t)$. For example, when the maximum inhibition of the photosynthesis was observed (11 March 1997), the average irradiance was 1 and 2 orders of magnitude higher in the UV-A and UV-B bands respectively in Stn S than in Stn N, while PAR irradiance was only 1.7 times higher (Table 1).

\section{Hydrology and water parameters}

The lagoon connected with the ocean $55 \%$ of the study period (ca. $15 \mathrm{mo}$ ) and presented 4 major marine intrusion events (Fig. 2). The periods when the system remained opened lasted for an average of ca. 2 mo. Half of the experiments were done under this hydrological condition.

Water depth ranged from 0.4 to $1.3 \mathrm{~m}$ for both stations and no significant differences were observed

Table 1. Average irradiance $(E)$ in the PAR, UV-A and UV-B bands received by the experiments, and inhibition of the PARsaturated photosynthetic rate attributed to UV-A and UV-B radiation, and to the full solar spectrum (UVT). The inhibition is expressed as the percentage difference between treatments, based on the PAR-saturated photosynthetic rate $\left(\right.$ at $\left.1000 \mu \mathrm{mol} \mathrm{m} \mathrm{m}^{-2}\right)$

\begin{tabular}{|c|c|c|c|c|c|c|c|c|c|c|c|c|}
\hline \multirow{3}{*}{ Date } & \multirow{2}{*}{\multicolumn{3}{|c|}{$\bar{E} \operatorname{Stn} \mathrm{S}$}} & \multirow{2}{*}{\multicolumn{3}{|c|}{$\overline{\text { Inhibition }-}$}} & \multirow{2}{*}{\multicolumn{3}{|c|}{$-\operatorname{Stn} \mathrm{N}$}} & \multirow{2}{*}{\multicolumn{3}{|c|}{ Inhibition- }} \\
\hline & & & & & & & & & & & & \\
\hline & $\begin{array}{c}\text { PAR } \\
\left(\mu \mathrm{mol} \mathrm{m} \mathrm{m}^{-2} \mathrm{~s}^{-1}\right)\end{array}$ & $\begin{array}{c}\text { UV-A } \\
\left(\mathrm{mW} \mathrm{cm}^{-2}\right)\end{array}$ & $\begin{array}{c}\text { UV-B } \\
\left(\mu \mathrm{Cm}^{-2}\right)\end{array}$ & UV-A & $\begin{array}{l}\text { UV-B } \\
(\%)\end{array}$ & UVT & $\begin{array}{c}\text { PAR } \\
\left(\mu \mathrm{mol} \mathrm{m} \mathrm{m}^{-2} \mathrm{~s}^{-1}\right)\end{array}$ & $\begin{array}{c}\mathrm{UV}-\mathrm{A} \\
\left(\mathrm{mW} \mathrm{\textrm {cm } ^ { - 2 }}\right)\end{array}$ & $\begin{array}{c}\text { UV-B } \\
\left(\mu \mathrm{W} \mathrm{cm}{ }^{-2}\right)\end{array}$ & UV-A & $\begin{array}{c}\text { UV-B } \\
(\%)\end{array}$ & UVT \\
\hline 11 Mar 97 & 1805.6 & 2.72 & 6.50 & 38.2 & 18.4 & 56.6 & 1083.3 & 0.22 & 0.06 & 1.4 & 0.7 & 2.1 \\
\hline 14 May 97 & 833.3 & 0.78 & 0.83 & 2.0 & 0.6 & 2.6 & - & - & - & - & - & - \\
\hline 11 Jun 97 & - & - & - & - & - & - & 820.3 & 0.28 & 0.18 & 0.3 & 0.1 & 0.4 \\
\hline 8 Aug 97 & 666.7 & 1.06 & 0.92 & -5.6 & -5.5 & -11.1 & 547.6 & 0.44 & 0.26 & 0.3 & 0.1 & 0.4 \\
\hline 21 Nov 97 & 833.3 & 0.53 & 0.28 & 0.2 & 0.0 & 0.2 & 827.4 & 0.55 & 0.36 & 6.2 & 3.3 & 9.5 \\
\hline 4 Dec 97 & 1694.4 & 1.50 & 2.03 & 10.2 & 5.1 & 15.3 & 968.2 & 0.45 & 0.28 & 5.2 & 4.1 & 9.3 \\
\hline 8 Jan 98 & 1305.6 & 0.53 & 0.19 & 1.3 & 1.0 & 2.3 & 918.9 & 0.22 & 0.03 & -9.3 & -0.7 & -10.0 \\
\hline 17 Feb 98 & 1611.1 & 2.14 & 3.58 & 25.0 & 12.5 & 37.5 & 1806.9 & 0.97 & 0.81 & 13.5 & 9.1 & 22.6 \\
\hline 3 Mar 98 & 1250.0 & 2.83 & 3.89 & 27.2 & 17.1 & 44.3 & 1457.3 & 0.57 & 0.40 & 7.2 & 2.6 & 9.8 \\
\hline 26 Nov 98 & 1083.3 & 1.94 & 3.50 & 19.5 & 7.0 & 26.5 & - & - & - & - & - & - \\
\hline 15 Dec 98 & 1388.9 & 2.19 & 3.36 & 19.0 & 9.6 & 28.6 & - & - & - & - & - & - \\
\hline 11 Jan 99 & 1555.6 & 0.86 & 0.47 & -10.1 & -3.4 & -13.5 & 1500.0 & 0.72 & 0.61 & 11.9 & 6.5 & 18.4 \\
\hline 9 Feb 99 & 1388.9 & 0.72 & 0.50 & 0.4 & 0.4 & 0.8 & 1166.7 & 0.75 & 0.50 & 3.3 & 0.6 & 3.9 \\
\hline 19 Feb 99 & 2111.1 & 2.89 & 5.11 & 29.0 & 15.2 & 44.2 & - & - & - & - & - & - \\
\hline 24 Feb 99 & 2055.6 & 3.19 & 5.00 & 24.7 & 11.1 & 35.8 & - & - & - & - & - & - \\
\hline 11 Mar 99 & 1694.4 & 3.08 & 5.22 & 30.3 & 12.2 & 42.5 & 1583.3 & 0.39 & 0.06 & 0.5 & 0.2 & 0.7 \\
\hline 20 May 99 & 805.6 & 0.81 & 0.64 & 0.6 & 1.2 & 1.8 & - & - & - & - & - & - \\
\hline
\end{tabular}


Table 2. Average and standard deviation (SD) of several abiotic and biological parameters of the water column at Stns $\mathrm{S}$ and $\mathrm{N}$ in Laguna de Rocha for open and closed bar periods. SRP: soluble reactive phosphorus

\begin{tabular}{|c|c|c|c|c|c|c|c|c|}
\hline \multirow{3}{*}{ Parameter } & \multicolumn{4}{|c|}{- Stn $\mathrm{S}$} & \multicolumn{4}{|c|}{ - Stn N } \\
\hline & \multicolumn{2}{|c|}{$\begin{array}{l}\text { Open } \\
\mathrm{n}=6\end{array}$} & \multicolumn{2}{|c|}{$\begin{array}{l}\text { Closed } \\
\mathrm{n}=10\end{array}$} & \multicolumn{2}{|c|}{$\begin{array}{l}\text { Open } \\
\mathrm{n}=5\end{array}$} & \multicolumn{2}{|c|}{$\begin{array}{c}\text { Closed } \\
\mathrm{n}=6\end{array}$} \\
\hline & Average & $\mathrm{SD}$ & Average & $\mathrm{SD}$ & Average & $\mathrm{SD}$ & Average & $\mathrm{SD}$ \\
\hline Depth (m) & 0.6 & 0.2 & 0.9 & 0.2 & 0.8 & 0.4 & 1.0 & 0.3 \\
\hline Temperature $\left({ }^{\circ} \mathrm{C}\right)$ & 21.8 & 2.5 & 18.1 & 4.6 & 23.1 & 2.6 & 20.6 & 4.4 \\
\hline Suspended inorganic solids $\left(\mathrm{mg} \mathrm{l}^{-1}\right.$ ) & 14.8 & 7.7 & 8.8 & 4.8 & 30.2 & 4.0 & 20.9 & 9.9 \\
\hline Suspended organic solids (mg l${ }^{-1}$ ) & 5.2 & 2.7 & 2.9 & 1.0 & 8.7 & 3.9 & 4.8 & 1.3 \\
\hline Dissolved oxygen $\left(\mathrm{mg} \mathrm{l}^{-1}\right)$ & 8.2 & 0.9 & 9.8 & 1.2 & 6.9 & 1.3 & 9.2 & 1.5 \\
\hline $\mathrm{pH}$ & 7.79 & 0.12 & 8.10 & 0.24 & 7.35 & 0.42 & 7.64 & 0.78 \\
\hline Conductivity $\left(\mathrm{mS} \mathrm{cm}^{-1}\right)$ & 16.9 & 14.7 & 18.0 & 8.7 & 6.7 & 8.6 & 4.0 & 3.7 \\
\hline Alkalinity (meq l ${ }^{-1}$ ) & 0.8 & 0.7 & 1.3 & 0.4 & 0.7 & 0.2 & 1.4 & 0.3 \\
\hline $\operatorname{SRP}\left(\mu g \mathrm{l}^{-1}\right)$ & 25.9 & 10.6 & 17.5 & 9.2 & 18.4 & 16.4 & 24.5 & 7.2 \\
\hline Nitrate $\left(\mu g \mathrm{l}^{-1}\right)$ & 69.2 & 26.8 & 62.8 & 19.2 & 95.1 & 115.1 & 61.7 & 14.1 \\
\hline Reactive silicate $\left(\mu \mathrm{gl}^{-1}\right)$ & 3102.0 & 1471.0 & 1839.0 & 1392.0 & 4164.0 & 2551.0 & 7068.0 & 3313.0 \\
\hline Nitrate/SRP (atomic ratio) & 6.2 & 2.3 & 9.7 & 5.3 & 9.9 & 2.7 & 5.9 & 1.9 \\
\hline Dissolved organic carbon $\left(\mathrm{mg} \mathrm{l}^{-1}\right)$ & 3.9 & 2.2 & 4.2 & 1.4 & 6.0 & 2.1 & 4.3 & 1.3 \\
\hline Chlorophyll a $\left(\mu \mathrm{g} \mathrm{l}^{-1}\right)$ & 3.6 & 0.7 & 4.3 & 1.8 & 5.8 & 4.9 & 8.9 & 7.0 \\
\hline Phytoplankton abundance (cells $\mathrm{ml}^{-1}$ ) & 1374 & 995 & 1745 & 81 & 1179 & 887 & 6237 & 9622 \\
\hline
\end{tabular}

between these 2 sites $(\mathrm{p}>0.5-t)$ (Table 2). Water depth was higher before each opening and after the marine intrusion, but decreased during the periods of water discharge into the ocean.

The conductivity varied from 0.10 to $45.7 \mathrm{mS} \mathrm{cm}^{-1}$ and was ca. 4 times higher at Stn S than at Stn N (p < $0.005-t$ ). Except during the second half of 1997, conductivity values were higher after the connection of the system with the ocean (Fig. 2A); however, this was only observed at Stn S. Although the system was connected with the ocean 4 times during 1997, the marine intrusion occurred only in March.

Two of the experiments performed to test the effects of UVR on phytoplankton photosynthesis were done under conductivity values $>30 \mathrm{mS} \mathrm{cm}^{-1}, 14$ from 10 to $30 \mathrm{mS} \mathrm{cm}^{-1}$, and 11 at a conductivity $<10 \mathrm{mS} \mathrm{cm}^{-1}$. Attenuation coefficients $\left(K_{\mathrm{d}}\right)$ for PAR, UV-A and UV-B (Fig. 2B,C) were approximately twice as high at Stn N compared to Stn $\mathrm{S}(\mathrm{p}<0.01-t)$. Values of $K_{\mathrm{d}}$ were inversely correlated with conductivity ( $\mathrm{r}$ for UV-A = -0.637 , r for UV-B $=-0.604 ; \mathrm{p}<0.05)$ at $\mathrm{Stn} \mathrm{S}$ but not at $\operatorname{Stn} \mathrm{N}(\mathrm{p}>0.5-t)$.

Water temperature did not exhibit significant differences between sampling stations $(\mathrm{p}>0.5-t)$ (Table 2). The concentration of total suspended solids ranged during the study from 3.4 to $121 \mathrm{mg} \mathrm{l}^{-1}$, with an organic content of ca. $1 / 3$ of the inorganic one (Table 2). For most sampling occasions, Stn $\mathrm{N}$ presented higher content of both fractions (1- to 6-fold) than Stn S (p < $0.05-t)$.

The DOC concentration ranged in the lagoon from 1.8 to $9.3 \mathrm{mg} \mathrm{l}^{-1}$ and it was commonly higher at the northern station (Table 2), although for the whole study period no significant differences were observed between sites $(p>0.5-t)$. The DOC content decreased during the marine intrusion events and was negatively correlated with conductivity at Stn S ( $\mathrm{r}=-0.459$; $\mathrm{p}<$ 0.05). A positive correlation was also found between DOC and UVR extinction coefficients for both sampling zones ( $\mathrm{r}$ for UV-A $=0.832, \mathrm{r}$ for UV-B $=0.763$; $\mathrm{p}<$ 0.001). Reactive silicate and nitrate presented higher concentrations at Stn $\mathrm{N}$ than at Stn $\mathrm{S}(\mathrm{p}<0.05-t)$, while the concentration of reactive soluble phosphorus did not differ between stations ( $p>0.5-t$ ) (Table 2). The nitrate/SRP atomic ratio was always $<8$, without significant differences between stations $(\mathrm{p}>0.5-t)$.

\section{Phytoplankton biomass, composition and photosynthetic capacity}

Chl a concentration in the lagoon ranged from 1.0 to $19.9 \mu \mathrm{g}^{-1}$ and although on average it was higher at Stn $\mathrm{N}$ than at $\mathrm{S}$ (Table 2), differences were not significant $(p>0.5-t)$. The highest chl a concentration occurred during summer; however, no clear seasonal pattern was observed (data not shown).

The phytoplankton abundance varied from 149 to 26900 cell ml-1, with similar values for both sampling stations except during February and March 1998, when at Stn $\mathrm{N}$ the abundance was higher than at Stn S $(\mathrm{p}<0.05-t$, Table 2). The phytoplankton at both stations was composed of 73 taxa from the divisions and classes Cyanobacteria, Bacillariophyceae, Prasino- 

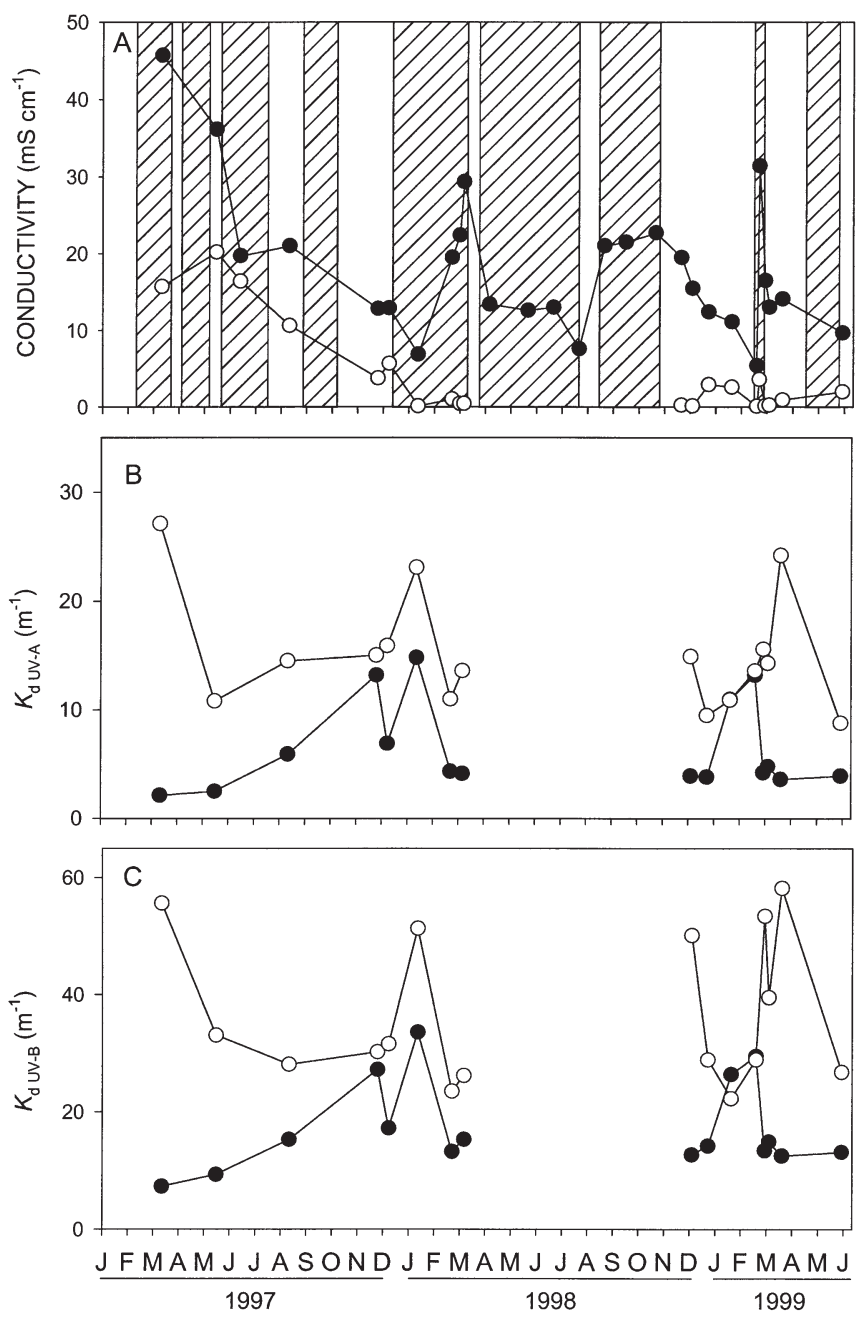

Fig. 2. Temporal changes in (A) conductivity and $(\mathrm{B}, \mathrm{C})$ attenuation coefficient in the UV-A waveband $\left(K_{\mathrm{d} \text { UV-A }}\right)$, and UV-B waveband $\left(K_{\mathrm{d} U V-\mathrm{B}}\right)$, respectively, at Laguna de Rocha (S: Stn South, $\bullet$;: Stn North, O). Shadowed areas represent periods when the lagoon connected with the Atlanctic Ocean. From April to October 1998, no $K_{\mathrm{d}}$ measurements and experiments were performed

phyceae, Chlorophyceae, Cryptophyceae, Dinophyceae, Euglenophyceae and small unidentified flagellates of length $\leq 8 \mu \mathrm{m}$. Bacillariophyceae was represented by 47 taxa and Chlorophyta by 16 , while the other divisions presented only up to 5 taxa. Diatoms (e.g. Chaetoceros subtilis var. abnormis f. simplex, Ch. aff. affinis, Cyclotella atomus, C. striata, C. meneghiniana, Nitzschia frustulum and N. paleaceae), dinoflagellates (Prorocentrum minimum) and cryptophyceans (Rhodomonas sp., Cryptomonas spp.) dominated numerically in both study areas. Green algae (Fortiella sp., Scenedesmus spp. and Monoraphidium sp.) were only present at Stn N, but never dominated the microalgal assemblage. Most dominant microalgae were typical
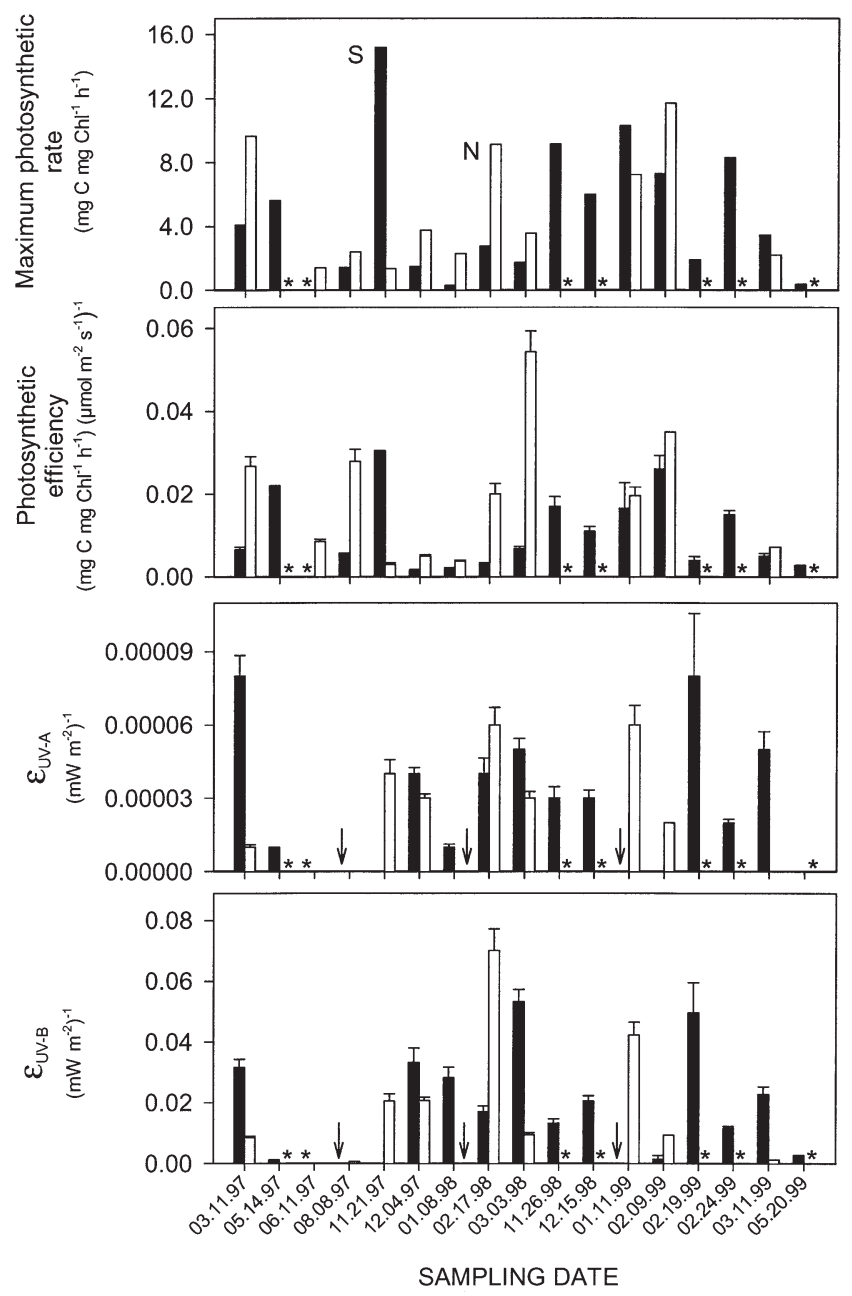

Fig. 3. Phytoplankton maximum photosynthetic rate (observed data), photosynthetic efficiency, and weights $(\varepsilon)$ in the UV-A and UV-B wavebands during the study at Stns N and S in Laguna de Rocha. Bars show the standard error of the estimates (for 8 August 1997 and 11 March 1999 at Stn N and for 9 February 1999 at Stn S estimates are not available because no convergence of the fit was attained). Asterisks indicate dates (mo.d.yr) when no experiments were performed. Arrows show experiments when negative estimates of the weights in the UV-A and UV-B wavebands were obtained

for brackish waters, while strict freshwater taxa did not contribute significantly to the total abundance and biomass. During some samplings (e.g. 11 March 1997), the marine diatom Thalassionema nitzschioides contributed significantly to the total abundance, but only at Stn S.

The phytoplankton PAR-saturated photosynthetic rate changed by 2 orders of magnitude during the study ( 0.3 to $15 \mathrm{mgC}$ [mg chl a $]^{-1} \mathrm{~h}^{-1}$ ) and exhibited a temporal trend with values close to $10 \mathrm{mgC}$ (mg $\operatorname{chl} a)^{-1} \mathrm{~h}^{-1}$ in summer and $<5 \mathrm{mgC}(\mathrm{mg} \operatorname{chl} a)^{-1} \mathrm{~h}^{-1}$ during winter and autumn (Fig. 3). The photosynthetic efficiency $\left(\alpha^{\mathrm{B}}\right)$ ranged from 0.002 to $0.054 \mathrm{mgC}$ (mg 

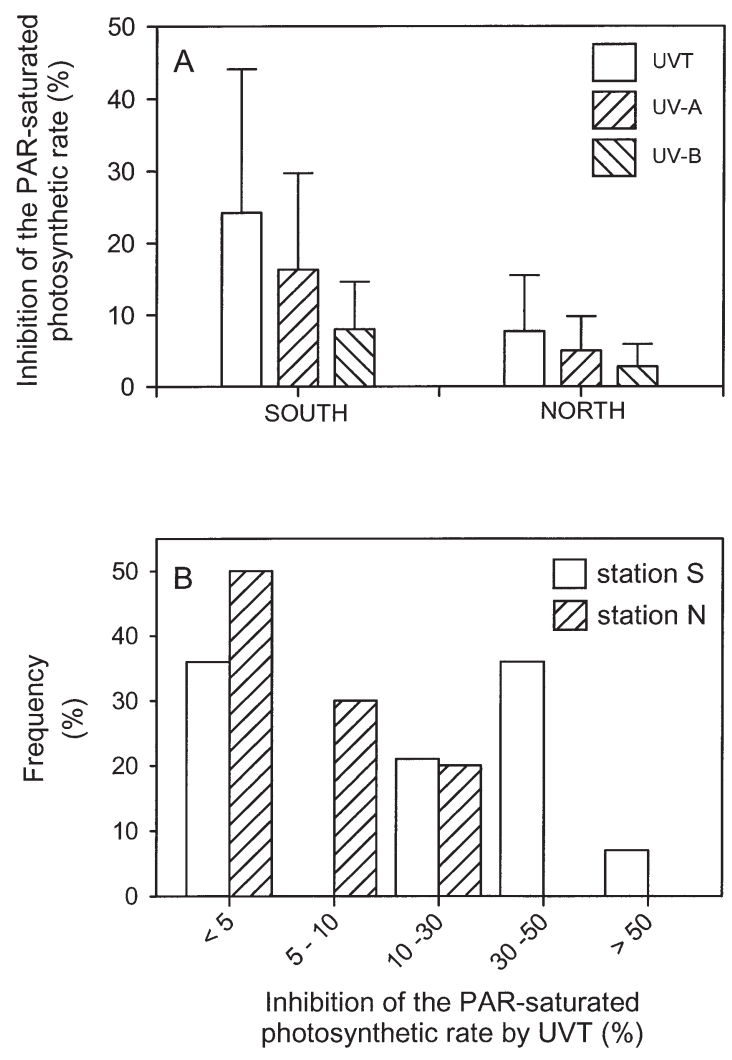

Fig. 4. (A) Average and standard deviation of the photosynthesis inhibition by UV-A, UV-B and the sum of both spectral wavebands (UVT) measured at Stns $\mathrm{S}$ and $\mathrm{N}$ in Laguna de Rocha. (B) Frequency distribution of the inhibition data according to 5 arbitrary ranges for sampling Stns $\mathrm{S}(\mathrm{n}=14)$ and $\mathrm{N}(\mathrm{n}=10)$

chl a) $)^{-1} \mathrm{~h}^{-1}\left(\mu \mathrm{mol} \mathrm{m}{ }^{-2} \mathrm{~s}^{-1}\right)^{-1}$ (Fig. 3), the standard errors representing $<10 \%$ of the estimates. The photoinhibition by PAR was low $\left(\alpha_{\text {PAR }}=1.1 \times 10^{-5}\right.$ to $2.2 \times 10^{-3}$ $\left[\mu \mathrm{mol} \mathrm{m} \mathrm{m}^{-2} \mathrm{~s}^{-1}\right]^{-1}$ ) and only observed at values above $700 \mu \mathrm{mol} \mathrm{m} \mathrm{m}^{-2} \mathrm{~s}^{-1}$ (data not shown), except for 2 experiments at Stn $\mathrm{N}$ performed during spring, when photoinhibition was found at ca. $450 \mu \mathrm{mol} \mathrm{m} \mathrm{m}^{-2} \mathrm{~s}^{-1}$. Phyto- plankton from Stn N commonly exhibited a lower photoinhibition threshold (450 to $1000 \mu \mathrm{mol} \mathrm{m} \mathrm{m}^{-2} \mathrm{~s}^{-1}$ ) than those from Stn S (800 to $1100 \mu \mathrm{mol} \mathrm{m} \mathrm{m}^{-2} \mathrm{~s}^{-1}$ ).

\section{Biological weights in the UV}

Using a non-linear regression procedure, we fitted the predicted photosynthetic rates to the observed ones, obtaining biological weightings for the UV-A and UV-B bands. In all but 2 cases, the predicted $P-E$ curves fit to the observed $P^{\mathrm{B}}$ values with $\mathrm{R}^{2}>0.95$. The calculated weights were 3 orders of magnitude higher in the UV-B band than in the UV-A one (Fig. 3). On average, the standard errors of the estimates in each band represented $<12 \%$. The biological weights in the UV range varied during the study period by up to 2 orders of magnitude, with the highest values found in summer and the lowest (or even negative in 3 cases exhibiting stimulation) in winter and autumn (Fig. 3). There was not a significant difference in $\varepsilon$ values between stations for both UV wavebands $(p>0.5-t)$.

In the UV-A band, the estimated weight (not taking into account those cases of photosynthesis stimulation seen under very low UVR) ranged from no sensitivity up to a maximum value of $8.0 \times 10^{-5}\left(\mathrm{~mW} \mathrm{~m}^{-2}\right)^{-1}$ (average $\varepsilon_{\mathrm{UV}-\mathrm{A}}=3.3 \times 10^{-5} \pm 2.7 \times 10^{-5}\left[\mathrm{~mW} \mathrm{~m}^{-2}\right]^{-1}$ for Stn $\mathrm{S}$ and $2.6 \times 10^{-5} \pm 2.3 \times 10^{-5}\left[\mathrm{~mW} \mathrm{~m}^{-2}\right]^{-1}$ for $\left.\mathrm{Stn} \mathrm{N}\right)$. In the UV-B band, the weights also varied from no sensitivity up to $7.0 \times 10^{-2}\left(\mathrm{~mW} \mathrm{~m}^{-2}\right)^{-1}$ (average $\varepsilon_{\mathrm{UV}-\mathrm{B}}=2.05 \times 10^{-2} \pm$ $1.73 \times 10^{-2}\left[\mathrm{~mW} \mathrm{~m}^{-2}\right]^{-1}$ for Stn S and $1.83 \times 10^{-2} \pm 2.23 \times$ $10^{-2}\left[\mathrm{~mW} \mathrm{~m}^{-2}\right]^{-1}$ for Stn N). The highest weights in the UV-A and UV-B bands coincided with the highest inhibition values at both sampling sites (Fig. 3, Table 1).

A multiple regression analysis performed for all experiments between $\varepsilon_{\mathrm{UV}-\mathrm{A}}$ and $\varepsilon_{\mathrm{UV}-\mathrm{B}}$ as dependent variables and potential influencing variables like underwater UV irradiances, UV attenuation coefficients, temperature and nitrate:SRP ratio, indicated that both the temperature and the nitrate:SRP ratio affected significantly phytoplankton sensitivity to UVR (Table 3).

Table 3. Multiple regressions relating phytoplankton sensitivity in the UV-A and UV-B wavebands $\left(\varepsilon_{U V-A}, \varepsilon_{U V-B}\right)$ with underwater UV-A and UV-B irradiances $\left(E_{\mathrm{UV}-\mathrm{A}}, E_{\mathrm{UV}-\mathrm{B}}\right)$, attenuation coefficients $\left(K_{\mathrm{d}} \mathrm{UV}-\mathrm{A}, K_{\mathrm{d}} \mathrm{UV}-\mathrm{B}\right)$, temperature $(T)$ and nitrate/SRP ratio $\left(\mathrm{NO}_{3} / \mathrm{SRP}\right)$ for all of the incubations performed during this study at Laguna de Rocha $(\mathrm{n}=21)$. ns: not significant

\begin{tabular}{|c|c|c|c|c|c|c|c|c|c|c|}
\hline \multirow{3}{*}{$\begin{array}{l}\text { Independent variables } \\
\text { Standardized coefficient }\end{array}$} & \multicolumn{4}{|c|}{$\begin{array}{l}\text { Dependent variable } \\
\varepsilon_{\mathrm{UV}-\mathrm{A}}\end{array}$} & & \multicolumn{5}{|c|}{$\begin{array}{l}\text { Dependent variable } \\
\varepsilon_{\mathrm{UV}-\mathrm{B}}\end{array}$} \\
\hline & $E_{\mathrm{UV}-\mathrm{A}}$ & $K_{\mathrm{d} \text { UV-A }}$ & $T$ & $\mathrm{NO}_{3} / \mathrm{SRP}$ & & $E_{\mathrm{UV}-\mathrm{B}}$ & $K_{\mathrm{d} \text { UV-B }}$ & $T$ & $\mathrm{NO}_{3} / \mathrm{SRP}$ & \\
\hline & ns & ns & 0.475 & -0.263 & & ns & ns & 0.476 & -0.205 & \\
\hline Constant & & & & & 0.08 & & & & & 1.20 \\
\hline Adjusted $r^{2}$ & & & & & 0.506 & & & & & 0.365 \\
\hline Model $\mathrm{p}<$ & & & & & 0.002 & & & & & 0.070 \\
\hline Standard error & & & & & 0.70 & & & & & 0.02 \\
\hline
\end{tabular}




\section{Effects of UVR on phytoplankton productivity}

Considering all experiments, the inhibition of the phytoplankton photosynthesis at saturating intensities when exposed to UVR was observed in ca. $90 \%$ of the cases (Table 1). The combined effect of UV-A and UV-B (UVT hereafter) on photosynthesis ranged from 56.6 to $-13.5 \%$ at Stn $\mathrm{S}$ and from 22.6 to $-10.0 \%$ at $\mathrm{Stn} \mathrm{N}$. The 3 negative results indicating stimulation of the photosynthetic rates corresponded to August 1997 and January 1999 at Stn S, and January 1998 at Stn N. On average, saturated photosynthesis was ca. $10 \%$ lower in the treatment including UV-A radiation compared to the treatment without UVR and ca. $15 \%$ lower in the full sunlight treatment. The average inhibition by UVT, UV-A and UV-B at Stn S was ca. 3-fold higher compared to the inhibition observed at Stn N.

Considering only the data where inhibition of the photosynthetic activity by UVR was observed (24 out of 27 experiments), $25 \%$ of the experiments exhibited an inhibition $>30 \%$, ca. $20 \%$ of the incubations presented an inhibition range from 10 to $30 \%$ while $54 \%$ were inhibited by $<10 \%$ (Table 1 ). On average, the inhibition by UVT was $24.2 \pm 19.9 \%$ at Stn $\mathrm{S}$ and $7.7 \pm 7.8 \%$ at Stn N (Fig. 4A). At both stations, the average inhibition by UV-A was twice as high as the inhibition observed by UV-B. At Stn S, $45 \%$ of the incubations presented an inhibition $>10 \%$, while at Stn $N, 80 \%$ of the experiments were inhibited by $<10 \%$ (Fig. 4B).

The photosynthesis inhibition by UVR varied considerably on a seasonal basis (Table 1). The highest levels ( $>35 \%$ ) were registered at Stn S during late summer (March 1997, February and March 1998, and February and March 1999), while the maximum inhibition at Stn N was observed in February 1998 (22.6\% by UVT). At both sampling sites, all experiments done during autumn-winter exhibited an inhibition $<5 \%$ (Table 1). All experiments done during spring-summer months that registered inhibition levels $<5 \%$ (including those that indicate stimulation) coincided with high UV attenuation coefficients $\left(K_{\mathrm{d} \text { UV-A }}<20 \mathrm{~m}^{-1}\right.$ and $>10 \mathrm{~m}^{-1}$ for Stns $\mathrm{N}$ and $\mathrm{S}$, respectively; $K_{\mathrm{d} U \mathrm{UV}-\mathrm{B}}<50 \mathrm{~m}^{-1}$ and $>$ $20 \mathrm{~m}^{-1}$ for Stns $\mathrm{N}$ and $\mathrm{S}$, respectively). Examples of these situations are March 1997 and March 1999 for Stn N, and January 1998 and February 1999 for Stn S (Fig. 2, Table 1).

\section{Relationships between inhibition and environmental variables}

Significant differences on phytoplankton relative photosynthetic rate were observed with the increment of underwater $E_{\mathrm{UV}-\mathrm{A}}$ and $E_{\mathrm{UV}-\mathrm{B}}$. For low irradiances (ca.
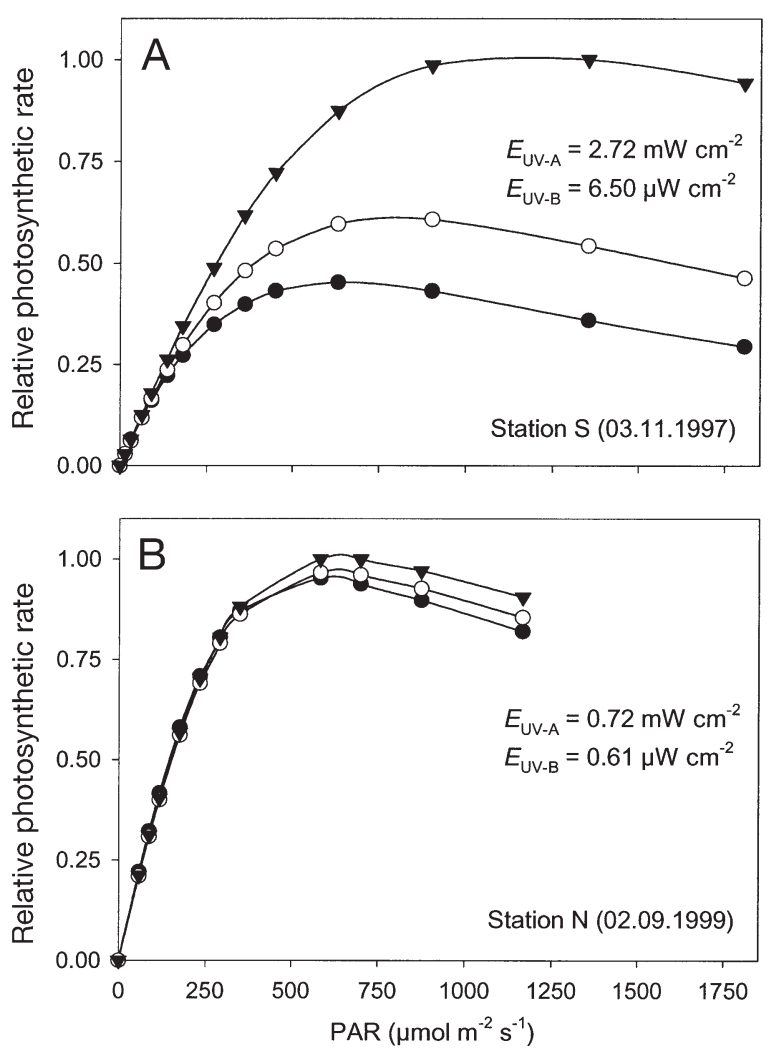

Fig. 5. Examples of predicted $P-E$ curves for (A) Stn $\mathrm{S}$ and (B) Stn N. In both cases, the average irradiances in the UV-A and UV-B bands $\left(E_{\mathrm{UV}-\mathrm{A}}, E_{\mathrm{UV}-\mathrm{B}}\right)$ received by the experiments are indicated and the predicted $P-E$ curve fit to the observed values with $\mathrm{R}^{2}>0.95$. The phytoplankton relative photosynthetic rate was estimated as the chlorophyll a (chl a)-specific photosynthetic rate for each PAR level, standardized by the chl a-specific maximum photosynthesis

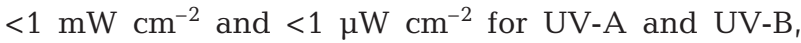
respectively), inhibition was not relevant, but when the irradiances increased 1 order of magnitude in both bands, inhibition reached up to 40 and $17 \%$, respectively (Fig. 5).

The photosynthesis inhibition found during the study period was not significantly correlated with the incident $E_{\mathrm{UV}-\mathrm{A}}$ and $E_{\mathrm{UV}-\mathrm{B}}(\mathrm{p}>0.1-\mathrm{r})$, but there was a positive correlation between the inhibition by each waveband and the average underwater irradiance (for UV-A: $\mathrm{r}=0.890, \mathrm{p}<0.0001$; for UV-B: $\mathrm{r}=0.875$, $\mathrm{p}<0.0001$ ) (Table 4). The inhibition by full sunlight was also positively correlated with the relationship $E_{\mathrm{UV}-\mathrm{B}} / E_{\mathrm{UV}-\mathrm{A}}(\mathrm{r}=0.870, \mathrm{p}<0.0001)$, as well as with the relationship $E_{\mathrm{UV}-\mathrm{A}}+E_{\mathrm{UV}-\mathrm{B}} / E_{\mathrm{PAR}}(\mathrm{r}=0.823, \mathrm{p}<$ 0.0001) (Table 4). The inhibition by UV-A, UV-B and UVT was positively correlated with the conductivity and negatively with the water depth, SOS, DOC and the attenuation coefficients in both UVR bands (Table 4). 
Table 4. Significant Pearson product-moment correlations (r) between the inhibition of the PAR-saturated phytoplankton photosynthetic rates by UV-A, UV-B and the full UVR spectrum (UVT) with selected optical, chemical and biological variables at Laguna de Rocha $(\mathrm{n}=24)$. For each case, the significance of the association is included. Underwater $E_{\mathrm{UV}-\mathrm{A}}$ and $E_{\mathrm{UV}-\mathrm{B}}$ are the average UV-A and UV-B irradiances received by the phytoplankton during the experiments (see text for other abbreviations)

\begin{tabular}{|c|c|c|c|c|c|c|}
\hline & \multicolumn{2}{|c|}{ Inhibition by UV-A } & \multicolumn{2}{|c|}{ Inhibition by UV-B } & \multicolumn{2}{|c|}{ Inhibition by UVT } \\
\hline & r & $\mathrm{p}<$ & $\mathrm{r}$ & $\mathrm{p}<$ & $\mathrm{r}$ & $\mathrm{p}<$ \\
\hline Conductivity & 0.469 & 0.05 & 0.400 & 0.05 & 0.451 & 0.05 \\
\hline Depth & -0.498 & 0.005 & -0.433 & 0.05 & -0.481 & 0.05 \\
\hline Organic suspended solids & -0.415 & 0.05 & -0.417 & 0.05 & -0.430 & 0.05 \\
\hline Dissolved organic carbon & -0.431 & 0.05 & -0.409 & 0.05 & -0.438 & 0.05 \\
\hline$K_{\mathrm{d} \text { UV-A }}$ & -0.610 & 0.001 & - & - & -0.611 & 0.001 \\
\hline$K_{\mathrm{d} \text { UV-B }}$ & - & - & -0.554 & 0.001 & -0.581 & 0.001 \\
\hline$\varepsilon_{\mathrm{UV}-\mathrm{A}}$ & 0.721 & 0.001 & - & - & 0.700 & 0.001 \\
\hline$\varepsilon_{\mathrm{UV}-\mathrm{B}}$ & - & - & 0.718 & 0.001 & 0.675 & 0.001 \\
\hline Underwater $E_{\mathrm{UV}-\mathrm{A}}$ & 0.890 & 0.0001 & - & - & - & - \\
\hline Underwater $E_{\mathrm{UV}-\mathrm{B}}$ & - & - & 0.875 & 0.0001 & - & - \\
\hline Underwater $E_{\mathrm{UV}-\mathrm{A}}+E_{\mathrm{UV}-\mathrm{B}} / E_{\mathrm{PAR}}$ & - & - & - & - & 0.823 & 0.0001 \\
\hline
\end{tabular}

\section{DISCUSSION}

\section{Effect of UVR on phytoplankton photosynthetic rates}

The effects of solar UVR on Laguna de Rocha primary production ranged from a slight stimulation (ca. $14 \%$ ) to a severe inhibition (up to ca. $55 \%$ ). A high variability in the photosynthesis inhibition by UVR was previously expected for this lagoon, given the recurrent short-term changes in bio-optical and chemical conditions, e.g. as a consequence of the sediment resuspension and mixing between marine and freshwaters (Conde et al. 1999, 2000). Almost $50 \%$ of the experiments presented an inhibition $>10 \%$, while those cases where the inhibition was $>30 \%$ were frequent (ca. $25 \%$ for all experiments and $45 \%$ for Stn S). On average, these results indicate that UVR reduced near-surface phytoplankton primary productivity in this lagoon by ca. $25 \%$. This value is within the range reported for phytoplankton (9 to $40 \%$ ) from the euphotic zone exposed to UVR at several coastal and offshore locations (Helbling et al. 1992, Smith et al. 1992, Prézelin et al. 1994, Vernet et al. 1994, Montecino \& Pizarro 1995, Boucher \& Prézelin 1996) and could be regarded as the maximum possible considering methodological constraints (i.e. exclusion of mixing, see next section). Considering that stratospheric ozone levels during the study period (average concentration $=283 \mathrm{DU}$ ) were within the range reported for this latitude (250 to $300 \mathrm{DU}$; CEC 1993), our results provide a baseline for future comparisons.

Photosynthesis stimulation in the treatments exposed to UVR was observed during autumn-winter (8 August 1997 at Stn S) or under situations of high UV attenuation (8 January 1998 at Stn N and 11 January 1999 in Stn S) (Table 1). The irradiance of UV-A rela- tive to UV-B was probably associated with this effect, since stimulation coincided with the highest underwater $E_{\mathrm{UV}-\mathrm{A}} / E_{\mathrm{UV}-\mathrm{B}}$ ratios (average was $\sim 3200$, while for the rest of the experiments it was $<1600$ ). Photosynthesis stimulation by UVR has been only reported by Nilawati et al. (1997), who found a similar effect for marine diatoms exposed under UV-B fluences ca. 10\% of the maximum summer level. The increase of the photosynthetic rate under low UV irradiance was probably related to the stimulation of recovery processes during the course of the experiments. For example, in the marine diatom Thalassiosira pseudonana, the balance between damage and recovering processes may take place $30 \mathrm{~min}$ after exposure to UV-B radiation (Cullen \& Lesser 1991). Alternatively, stimulation may result from an experimental artifact caused by the use of Mylar and vinyl chloride foils that slightly reduce the transmittance over the PAR range in comparison to quartz glass.

Although the variation of the inhibition did show a temporal trend (i.e. highest levels in summer and lowest in winter for both study areas), not all incubations under high incident UVR in summer presented inhibition, because the effects also depended on the water UV transparency (see below). In winter, the underwater $E_{\text {PAR }}$ received by the samples from the clearest site (Stn S) did not exceed $840 \mu \mathrm{mol} \mathrm{m}^{-2} \mathrm{~s}^{-1}$, while maximum $E_{\mathrm{UV}-\mathrm{A}}$ and $E_{\mathrm{UV}-\mathrm{B}}$ measured with our broadband IL1400A radiometer were $1.06 \mathrm{~mW} \mathrm{~cm}^{-2}$ and $0.92 \mu \mathrm{W}$ $\mathrm{cm}^{-2}$, respectively. This suggests that UVR received by the phytoplankton in the marine influence area of Laguna de Rocha must overcome these threshold irradiance values to cause significant reductions in the photosynthetic activity.

Even though a high sensitivity of phytoplankton to UV-B radiation was found, the average inhibition by 
UV-A was almost double that by UV-B. The dominance of the UV-A waveband on the inhibition of photosynthetic rates in Laguna de Rocha is in agreement with results from other studies done under normal and even reduced ozone concentrations (Smith et al. 1992, Kim \& Watanabe 1993, Callieri et al. 2001, Neale et al. 2001). While it is apparent that the UV-A waveband has a higher integrated energy than UV-B in the solar spectrum and penetrates deeper in the water column, inhibition ratios attributed to the different UV wavebands should be done with caution as it may be affected by the type of cut-off material used by different authors. For example, Williamson et al. (2001) found that when the transmittance of the thinnest Mylar D (23 $\mu$ m thickness, $50 \%$ transmittance at $316 \mathrm{~nm}$ ) is multiplied by the solar spectrum for $\sim 40^{\circ} \mathrm{N}$ latitude near summer solstice, it cuts out only $60 \%$ of UV-B energy $(<320 \mathrm{~nm})$. Because increasing thickness of Mylar D affects the cut-off wavelength and the amount of energy excluded (R. Sommaruga unpubl. data), the magnitude of the effect attributed to UV-B and UV-A will change.

\section{Main factors modifying the overall effect of UVR on phytoplankton}

Our results indicate that both incident irradiance and attenuation, and microalgal sensitivity ( $\varepsilon_{\mathrm{UV}-\mathrm{A}}$ and $\left.\varepsilon_{\mathrm{UV}-\mathrm{B}}\right)$ were important to understand the inhibition of phytoplankton photosynthesis in this system. The broadband nature of our UVR sensors does not permit a strict comparison of the UV weights for Laguna de Rocha with other BWFs; however, they do give a broad estimate of the phytoplankton sensitivity. Our estimates, especially in the UV-A band, are within the range of the BWFs found for phytoplankton from estuarine environments in the North Hemisphere and coastal locations in Antarctica, as well as for freshwater lakes (Neale et al. 1998, 2001, Banaszak \& Neale 2001). Our estimates of the $\varepsilon_{\mathrm{UV}-\mathrm{B}}$ were higher compared to published BWFs. This could be explained by the possibility that the effective bandwidth of our SUL240/W sensor is less than 20 (see comments on the UV-B sensor in 'Materials and methods'), which would underestimate the actual $E_{\mathrm{UV}-\mathrm{B}}$, leading to an overestimation of the weights. Taking into account the maximum sensitivity of our broadband UV radiometer (IL1400A centered in $311 \mathrm{~nm}$ for UV-B and $365 \mathrm{~nm}$ for UV-A), our values were higher in the shorter band (1 to 2 orders of magnitude) but lower (1 order of magnitude) in the UV-A, compared to the biological weighting function for Rhode River (average BWF for the spring) reported by Banaszak \& Neale (2001) for phytoplankton photosynthesis. For the Rhode River, inhibition values of depthintegrated midday primary production of up to $33 \%$ in the presence of UVR were found (Banaszak \& Neale 2001), which is close to our average inhibition data for Laguna de Rocha, although in our case the data correspond to a depth of $10 \mathrm{~cm}$. The summer surface inhibition of the midday primary production found by Neale (2001) in the Rhode River accounted for an average of up to $61 \%$.

Both $\varepsilon_{\mathrm{UV}-\mathrm{A}}$ and $\varepsilon_{\mathrm{UV}-\mathrm{B}}$ varied during this 2 yr study by almost 2 orders of magnitude in the UV-B waveband and by almost 1 order of magnitude in the UV-A. This variability was associated to seasonal changes in water temperature and in the nitrate/SRP ratio. The nutritional status of phytoplankton seems to be relevant for the sensitivity to UVR (Cullen \& Lesser 1991, Behrenfeld et al. 1994, Karentz et al. 1994). Particularly, nitrogen limitation (Lesser et al. 1994, Moeller 1994) may compromise the synthesis of photoprotective substances such as MAAs and proteins related to the repair processes (Neale 1987, Litchman et al. 2002), as well as of those enzymes associated to the carbon fixation process (Falkowski \& Raven 1997). The atomic ratio of nitrate/SRP at Laguna de Rocha was generally low $(<8)$, suggesting that nitrogen was often limiting (Guildford \& Hecky 2000). Furthermore, results from experiments of nutrient enrichment with phytoplankton from this lagoon have confirmed a strong $\mathrm{N}$ limitation during the whole annual cycle (S. Bonilla unpubl. data).

The community structure is probably another important factor related to the sensitivity observed. Several taxa that composed the phytoplankton assemblages of Laguna de Rocha, such as the diatoms Nitzschia spp. and Chaetoceros sp. have previously been reported as highly sensitive to UVR (Hazzard et al. 1997, Nilawati et al. 1997). In fact, maximum levels of inhibition were coincident with the dominance of diatoms. For example, when the community at Stn S was dominated by diatoms $(70 \%$ of the total abundance; Chaetoceros cf. tenuissimus, Cyclotella atomus, Melosira dubia and Nitzschia spp.), the inhibition of photosynthesis was $>50 \%$.

On several occasions, we assessed the presence of intracellular UV-absorbing compounds in phytoplankton from Laguna de Rocha by measuring spectral absorbance in the UV range of methanol extracts (25 to $100 \%$ ). However, characteristic peaks in the UV range were not observed. Although HPLC analyses would have been necessary to confirm this observation, there is evidence that not all phytoplankton groups efficiently synthesize MAAs. For example, in a study with 152 marine microalgae species, concentrations of UVabsorbing compounds, as determined by the ratio of maximum absorbance in the UV to the chl a absorbance at $665 \mathrm{~nm}$, was highest in dinoflagellates and lowest in diatoms, eustigmatophytes, chlorophytes, pra- 
sinophytes, cyanophytes, euglenophytes and rhodophytes (Jeffrey et al. 1999). The numerical dominance in our study of small diatoms at both sampling sites together with model predictions that suggest smallsize phytoplankton species cannot efficiently synthesize MAAs (Garcia-Pichel 1994) and the observed $\mathrm{N}$-limitation in the lagoon may explain the apparent absence of these protective compounds. Furthermore, phytoplankton from lakes with low UV transparency generally present very low MAA concentrations (Laurion et al. 2002).

One important characteristic of Laguna de Rocha and many other shallow coastal lagoons is the polymixis associated with daily wind patterns (Conde et al. 1999 , 2000). Generally, from ca. 12:00 to 17:00 h, i.e. at time of the highest incident UVR, algal cells are subject to a strong vertical circulation in a shallow water column. As discussed by Neale et al. (1998), mixing may and may not be beneficial for phytoplankton, depending on the relationship between UV penetration and mixing depth. As shown for Lake Lucerne, UVR seriously reduces microalgal photosynthesis when the euphotic zone exceeded the mixing depth (Köhler et al. 2001). Our experiments at Laguna de Rocha were done at a fixed depth, however, considering that the average $10 \%$ penetration depth for the whole study reached not more than 60 and $15 \%$ of the water column for UV-A and UV-B, respectively (Conde et al. 2000), vertical mixing might represent a crucial mechanism for phytoplankton to minimize UV damage (especially by UV-B). On the other hand, in those situations of high inhibition coinciding with low UV-attenuation and a high euphotic depth/mixing depth ratio (for example Stn S on 11 March 1997; $10 \%$ penetration depth for UV-A and UV-B $=100$ and $60 \%$ of the water column, respectively), vertical mixing appeared not to significantly protect phytoplankton against UVR.

\section{Influence of the hydrological regime on the inhibition}

The variation in inhibition of phytoplankton photosynthesis by UVR at Laguna de Rocha can be explained by the influence of the hydrological regime on the UV attenuation coefficients and by the entrapment of microalgae originating from the coastal zone in a very shallow water column. The underwater UV attenuation was generally significantly lower in the brackish area (Stn S), especially after events of marine intrusion, as previously reported for this system (Conde et al. 2000). While the system was connected with the ocean 3 times from April 1997 to January 1998, no marine intrusion was observed until February 1998 when strong southeastern winds dominated. This also explains why the
UV penetration into the water column was low and photosynthesis inhibition did not exceed $15 \%$ even under high incident UVR. All other connection events of the lagoon with the ocean were followed by the intrusion of coastal waters, which coincided with high photosynthesis inhibition values during summer at Stn S (inhibition ranged from ca. 27 to $44 \%$ ).

The highest inhibition levels at Stn S were observed during days of high incident UVR, but only when coincident with periods of marine intrusion and therefore low $K_{\mathrm{d}}$. Thus, the highest photosynthetic rate reduction occurred at $K_{\mathrm{d} \text { UV-A }}<5 \mathrm{~m}^{-1}$ and $K_{\mathrm{d} \text { UV-B }}<15 \mathrm{~m}^{-1}$. Under the influence of fluvial discharge, rich in CDOM and POM, no significant inhibition was observed. At the Stn $N$, the inhibition was commonly $<10 \%$ and only important when relatively low $K_{\mathrm{d}}$ values for UV were observed (e.g. February 1998 and January 1999). However, low UV attenuation in this zone is not a consequence of the marine influence as shown by low conductivity values, but by the occurrence of calm periods when less UV-attenuating substances are introduced by sediment resuspension (Conde et al. 2000).

Considering the potential increase of UV-B expected for the next decades at this latitude (Sze et al. 1989) and based on our results, the overall impact on phytoplankton primary productivity of this ecosystem seems to be minor to moderate. However, a process that may have greater relevance for the impact on productivity than the change in concentrations of stratospheric ozone itself is the decrease of UV attenuation in the water column associated with lower CDOM inputs from the catchment as reported by several authors (Schindler et al. 1996, Williamson et al. 1996, Vincent et al. 1998, Kuhn et al. 1999, Neale et al. 2001). The precipitation regime in southeastern Uruguay and southern Brazil has suffered important modifications during the last decade as a consequence of the El Niño/La Niña events, to which extreme rainfall and drought are respectively associated (Genta et al. 1998). Dry years could have 2 potentially opposing effects. First, lower inputs of UV-attenuating substances in comparison with periods of high runoff will decrease UV attenuation, especially in the northern part of the system where the biota is pre-adapted to a turbid environment. On the other hand, the reduction of river discharge will also prevent the communication of the lagoon with the ocean; thus, hampering the intrusion of coastal waters with lower concentrations of UV-attenuating substances into the southern zone. Therefore, considering that the communication of the lagoon with the ocean and the following marine intrusion are key processes for phytoplankton photoinhibition at the brackish end of the system, our results have important implications for the management (e.g. opening of the sand bar by human action) of these very productive ecosystems. 
Acknowledgements. We would like to thank Dr. Patrick Neale for his valuable assistance with calculations, comments and suggestions that improved the quality of the manuscript. We also thank Javier Gorga and Juan Clemente for helping during sampling, and Yasunori Watanabe for providing the vinyl chloride foil. This study was financed by grants from CONICYT-Uruguay (2086), CSIC-Universidad de la República (071), IFS-Sweden (A/2917-1) to D.C. and the Austrian Science Foundation (P14153-BIO) to R.S.

\section{LITERATURE CITED}

APHA (American Public Health Association) (1995) Standard methods for the examination of water and wastewater. APHA/AWWA/WPCF, Washington, DC

Banaszak AT, Neale PJ (2001) Ultraviolet radiation sensitivity of photosynthesis in phytoplankton from an estuarine environment. Limnol Oceanogr 46:592-603

Behrenfeld MJ, Lee H II, Small LF (1994) Interaction between nutritional status and long-term responses to ultraviolet $\mathrm{B}$ radiation stress in a marine diatom. Mar Biol 118:523-530

Benner R, Strom M (1993) A critical evaluation of the analytic blank associated with DOC measurements by hightemperature catalytic oxidation. Mar Chem 41:153-160

Boucher NP, Prézelin BB (1996) Spectral modeling of UV inhibition of in situ Antarctic primary production using a field-derived biological weighting function. Photochem Photobiol 64:407-418

Callieri C, Morabito G, Huot Y, Neale P, Litchman E (2001) Photosynthetic response of pico- and nanoplanktonic algae to UVB, UVA and PAR in a high mountain lake. Aquat Sci 63:286-293

CEC (Commission of the European Communities) (1993) Environmental UV radiation. In: Acevedo J, Nolan C (eds) Causes-effects-consequences, DG XII / D-1.Commission of the European Communities, Directorate-General XII for Science, Research and Development, Brussels, p 78

Comín FA, Valiela I (1993) On the controls of phytoplankton abundance and production in coastal lagoons. J Coastal Res 9:895-906

Conde D, Sommaruga R (1999) A review of the state of limnology in Uruguay. In: Wetzel RG, Gopal B (eds) Limnology in developing countries. International Association of Theoretical and Applied Limnology, Vol 2. International Scientific Publications, New Delhi, p 1-31

Conde D, Bonilla S, Aubriot L, De León R, Pintos W (1999) Comparison of the areal amount of chlorophyll $a$ of planktonic and attached microalgae in a shallow coastal lagoon. Hydrobiologia 408/409:285-291

Conde D, Aubriot L, Sommaruga R (2000) Changes in UV penetration associated with marine intrusions and freshwater discharge in a shallow coastal lagoon of the Southern Atlantic Ocean. Mar Ecol Prog Ser 207:19-31

Costanza R, Kemp WM, Boynton WR (1993) Predictability, scale and biodiversity in coastal and estuarine ecosystems: implications for management. Ambio 22:88-96

Cullen JJ, Lesser MP (1991) Inhibition of photosynthesis by ultraviolet radiation as a function of dosage and dosage rate: results from a marine diatom. Mar Biol 111:183-191

Falkowski PG, Raven JA (1997) Aquatic photosynthesis. Blackwell Science, Malden

Garcia-Pichel F (1994) A model for self-shading in planktonic organisms and its implications for the usefulness of ultraviolet sunscreens. Limnol Oceanogr 39:1704-1717

Gätcher R, Mares A, Tilzer MM (1984) Determination of phytoplankton production by the radiocarbon method: a comparison between the acidification and bubbling method (ABM) and the filtration technique. J Plankton Res 6:359-364

Genta JL, Pérez G, Mechoso CR (1998) A recent increasing trend in the streamflow of rivers in southeastern South America. J Climate 11:2858-2862

Guildford SJ, Hecky RE (2000) Total nitrogen, total phosphorus, and nutrient limitation in lakes and oceans: is there a common relationship? Limnol Oceanogr 45:1213-1223

Hasle F (1978) Counting phytoplankton. In: Sournia A (ed) Phytoplankton manual. Monographs in oceanographic methodology, Vol 6. UNESCO, Paris, p 88-96

Hazzard C, Lesser MP, Kinzie RA III (1997) Effects of ultraviolet radiation on photosynthesis in the subtropical marine diatom, Chaetoceros gracilis (Bacillariophyceae). J Phycol 33:960-968

Helbling EW, Villafañe V, Ferrario M, Holm-Hansen O (1992) Impact of natural ultraviolet radiation on rates of photosynthesis and on specific marine phytoplankton species. Mar Ecol Prog Ser 80:89-100

Jassby AD, Platt T (1976) Mathematical formulations of the relationship between photosynthesis and light for phytoplankton. Limnol Oceanogr 21:540-547

Jeffrey SW, Humphrey JD (1975) New spectrophotometric equations for determining chlorophylls $a, b$ and $c$ and $c 1$ in higher plants, algae and natural phytoplankton. Biochem Physiol Pflanz 167:191-194

Jeffrey SW, McTavish HS, Dunlap WC, Vesk M, Groenewoud K (1999) Occurrence of UVA- and UVB-absorbing compounds in 152 species (206 strains) of marine microalgae. Mar Ecol Prog Ser 189:35-51

Karentz D, Bothwell ML, Coffin RB, Hansson A and 10 others (1994) Impact of UV-B radiation on pelagic freshwater ecosystems: report of working group on bacteria and phytoplankton. Arch Hydrobiol Beih Ergebn Limnol 43: 31-69

Kim DS, Watanabe Y (1993) The effect of long wave ultraviolet radiation (UV-A) on the photosynthetic activity of natural population of freshwater phytoplankton. Ecol Res $8: 225-234$

Kirchhoff VW, Scuch NJ, Pinheiro DK, Harris JM (1996) Evidence for an ozone hole perturbation at $30^{\circ}$ south. Atmos Environ 30:1481-1488

Kirk JTO (1994) Light and photosynthesis in aquatic ecosystems. Cambridge University Press, Cambridge, p 524

Kirk JTO, Heargraves BR, Morris DP, Coffin RB and 9 others (1994) Measurements of UV-B radiation in two freshwater lakes: an instrument intercomparison. Arch Hydrobiol Beih Ergebn Limnol 43:71-99

Köhler J, Schmitt M, Krumbck H, Kapfer M, Litchman E, Neale P (2001) Effects of UV on carbon assimilation of phytoplankton in a mixed water column. Aquat Sci 63: 294-309

Kuhn P, Browman H, McArthur B, St-Pierre JF (1999) Penetration of ultraviolet radiation in the waters of the estuary and Gulf of St Lawrence. Limnol Oceanogr 44:710-716

Laurion I, Lami A, Sommaruga R (2002) Distribution of mycosporine-like amino acids and photoprotective carotenoids among freshwater phytoplankton assemblages. Aquat Microb Ecol 26:283-294

Lesser MP, Cullen JJ, Neale PJ (1994) Carbon uptake in a marine diatom during acute exposure to ultraviolet $\mathrm{B}$ radiation: relative importance of damage and repair. J Phycol 30:183-192

Litchman E, Neale PJ, Banaszak AT (2002) Increased sensitivity to ultraviolet radiation in nitrogen-limited dinoflagellates: photoprotection and repair. Limnol Oceanogr 47:86-94 
Lohrenz SE (1993) Estimation of primary production by the simulated in situ method. ICES Mar Sci Symp 197: 159-171

Mechoso CR, Pérez-Iribarren G (1992) Streamflow in southeastern South America and the Southern Oscillation. J Clim 5:1535-1539

Moeller RE (1994) Contribution of ultraviolet radiation (UV-A, UV-B) to photoinhibition of epilimnetic phytoplankton in lakes of differing UV transparency. Arch Hydrobiol Beih Ergebn 43:157-170

Montecino V, Pizarro G (1995) Phytoplankton acclimation and spectral penetration of UV irradiance off the central Chilean coast. Mar Ecol Prog Ser 121:261-269

Neale PJ (1987) Algal photoinhibition and photosynthesis in the aquatic environment. In: Kyle DJ, Osmond CB, Arntzen CJ (eds) Photoinhibition. Elsevier Science Publishers, New York, p 35-65

Neale PJ (2001) Modelling the effects of ultraviolet radiation on estuarine phytoplankton production: impact of variations in exposure and sensitivity to inhibition. J Photochem Photobiol 62:1-8

Neale PJ, Davis RF, Cullen JJ (1998) Interactive effects of ozone depletion and vertical mixing on photosynthesis Antarctic phytoplankton. Nature 392:585-589

Neale P, Litchman E, Sobrino C, Callieri C and 6 others (2001) Quantifying the response of phytoplankton photosynthesis to ultraviolet radiation: biological weighting functions versus in situ measurements in two Swiss lakes. Aquat Sci 63:265-285

Nilawati J, Greenberg BM, Smith RE (1997) Influence of ultraviolet radiation on growth and photosynthesis of two cold ocean diatoms. J Phycol 33:215-224

Piazena H, Häder DP (1994) Penetration of solar UV irradiation in coastal lagoons of the Southern Baltic Sea and its effect on phytoplankton communities. Photochem Photobiol 60:463-469

Prézelin BB, Boucher NP, Smith RC (1994) Marine primary production under the influence of the Antarctic ozone hole: icecolors '90. In: Weiler CS, Penhale PA (eds) Ultraviolet radiation in Antarctica: measurements and biological effects. Antarctic Research Series, Vol 62. American Geophysical Union, Washington, DC, p 159-186

Schindler DW, Curtis PJ, Parker BR, Stainton MP (1996) Consequence of climate warming and lake acidification for

Editorial responsibility: Howard Browman (Contributing Editor), Storebø, Norway
UV-B penetration in North American boreal lakes. Nature 379:705-708

Smith RC, Prézelin BB, Baker KS, Bidigare RR and 9 others (1992) Ozone depletion: ultraviolet radiation and phytoplankton biology in Antarctic waters. Science 255:952-959

Sommaruga R, Pintos W (1991) Laguna de Rocha. In: LBRI / ILEC (eds) Data book of world lake environments: a survey of the state of world lakes, SAM-9, LBRI/ILEC. Otsu, Japan

Stedmon CA, Markager S, Kaasb H (2000) Optical properties and signatures of chromophoric dissolved organic matter (CDOM) in Danish coastal waters. Estuar Coast Shelf Sci 51:267-278

Steeman-Nielsen E (1952) The use of radiactive carbon $\left({ }^{14} \mathrm{C}\right)$ for measuring organic production in the sea. J Cons Int Explor Mer 18:117-140

Sze ND, Ko KW, Weisenstein DK, Rodríguez JM, Stolarski RS, Schoeberl MR (1989) Antarctic ozone hole: possible implications for ozone trends in the southern hemisphere. J Geophys Res 94:11521-11528

Tomas CR (1997) Identifying marine phytoplankton. Academic Press, San Diego

Vernet ME, Brody A, Holm-Hansen O, Mitchell BG (1994) The response of Antarctic phytoplankton to ultraviolet radiation: absorption, photosynthesis, and taxonomic composition. In: Weiler CS, Penhale PA (eds) Ultraviolet radiation in Antarctica: measurements and biological effects. American Geophysical Union, Washington, DC. Antarctic Research Series, Vol 62, p 143-158

Vincent WF, Roy S (1993) Solar ultraviolet-B radiation and aquatic primary production: damage, protection and recovery. Environ Rev 1:1-12

Vincent WF, Laurion I, Pienitz R (1998) Arctic and Antarctic lakes as global indicators of global change. Ann Glaciol 27:691-696

Williamson CE, Stemberger RS, Morris DP, Frost TM, Paulsen SG (1996) Ultraviolet radiation in North American lakes: attenuation estimates from DOC measurements and implications for plankton communities. Limnol Oceanogr 41: 1024-1034

Williamson CE, Neale PJ, Grad G, De Lange HJ, Hargreaves BR (2001) Beneficial and detrimental effects of UV radiation on aquatic organisms: implications of variation in spectral composition. Ecol Appl 11:1843-1857

Submitted: December 7, 2001; Accepted: June 4, 2002

Proofs received from author(s): August 16, 2002 